\title{
Effective Ways of Motivating Adults for Learning in Professional Field
}

\author{
Ludmila Michailovna Levina $^{1} \&$ Valeria Valerievna Mariko ${ }^{1}$ \\ ${ }^{1}$ Lobachevsky State University of Nizhni Novgorod -National Research University, Nizhny Novgorod, Russia \\ Correspondence: Ludmila Michailovna Levina, Lobachevsky State University of Nizhni Novgorod -National \\ Research University, 603950, pr. Gagarina, 23, Nizhny Novgorod, Russia. E-mail: pr@unn.ru
}

Received: July 30, 2014 Accepted: September 30, 2014 Online Published: December 30, 2014

doi:10.5539/ass.v11n3p235 URL: http://dx.doi.org/10.5539/ass.v11n3p235

\begin{abstract}
The article highlights the problem of fostering motivation for professional development in adult learners. It describes the methodology of autonomy-supportive educational practices applicable to designing innovative competence-oriented ERR-based in-service training programs at university. It presents the ways of cognitive and emotional support in the individual and collective zone of proximal development of in-service training participants. The aim of the study also is to identify key areas of development programs of additional professional education, examines the experience of UNN on a number of programs to draw conclusions about the future development of other related, those described in the article directions and retraining programs and the forecast potential outcomes.
\end{abstract}

Keywords: adult education, in-service training, motivation, self-determination theory, autonomy, competence, relatedness, communication, active methods, scaffolding strategies

\section{Introduction}

In the last decades adult learning has become one of the most important elements of lifelong learning, in which professional competence-oriented development plays an essential role. It brings forward a growing demand in adult educators as the leading agents of this change. Accordingly, professional development of adult educators, able to manage their own development as well as the development of those whom they mentor tends to turn into the key component of competence-oriented in-service training for university faculty. Promoting and maintaining volitional motivation of adult learners in autonomy-supportive environment stimulates their growth and increases the efficiency of education.

In this context the motivational theory of self-determination (Ryan \& Deci, 2012a) serves the basis for development of more efficient in-service training programs at university. Self-determination theory assumes that propensity to learn and develop is innate and expresses itself through proactive and future oriented behaviors. Such behaviors are promoted by three types of motivation: intrinsic, integrated and identified (Ryan \& Deci, 2012b). Extensive research has proved that behaviors resulting from these three forms of motivation vary in the level of self-determination. Intrinsic motivation has the most positive impact on cognitive, behavioral, and emotional aspects of learning, while identified motivation - the least positive (Ryan \& Deci, 2013a). Evidence suggests that this effect decreases with the degree of extrinsic determination when external controls introduced into the learning environment affect the psychological processes connected with high-quality learning (Ryan \& Deci, 2013b; Wilkesmann \& Schmid, 2014).

Speculating about double dimension of learner's self-direction in which (within a socio-cognitive perspective) self-determined motivation and self-regulations function in interdependent relationship, A. Jézégou emphasizes that a high level of initial motivation is necessary to involve oneself in an activity to achieve a personal goal, while self-regulation is necessary for other aspects of this initial activity. Self-regulation processes are important for maintaining this motivation during the activity. This motivation is both the source and consequence of this process (Jézégou, 2012).

As an urge to satisfy basic psychological needs for autonomy (feeling of being the origin of one's own behaviors), competence (feeling effective), and relatedness (feeling understood and cared for by others) is at the 
core of self-directed motivation, creating conditions supporting learners' experiences in autonomy, competence and relatedness will foster students' active engagement in learning (Vansteenkiste, Niemiec, \& Soenens, 2010).

We also used Albert Bandura's competence staircase as a developmental approach to leading adult learners from subconscious incompetence through supraliminal incompetence and subconscious competence to, finally, supraliminal competence in the course of in-service training (Rodikov, 2010). The model gains its specific meaning in career development training courses for adults. In any learning process a learner has to make steps. Starting to act the person faces an obstacle which he didn't suspect of - his/her ignorance or incompetence. Transition from subconscious incompetence to supraliminal competence causes frustration and disappointment. These feelings may stop the process of development and self-perfection and the phase of gaining subconscious competence will never occur. Frustration may also have a positive impact as the leading motivation factor to start learning. At this stage it's important to distance yourself from subjective perception, to analyze strengths and weaknesses, and develop an educational strategy. Passive submission to negative emotions leads to absolute demotivation and failure. Overcoming frustration the person experiences the feeling of relief and self-assertion. Objective analysis of your potential leads to active acquisition of new knowledge. At some moment active assimilation of new information may cause confusion, which the learner should treat positively as a sign of a successful educational process. At the moment of confusion the clash of new knowledge with older concepts and prior knowledge results in reconsidering the previous experience. It evokes the joy of discovery and anticipation of success. This way the learner quickly reaches the stage of conscious competence.

According to M. Beyer, transition from one competence stage to another is accompanied by the following state of the person: moving from subconscious incompetence to supraliminal incompetence is accompanied by frustration; moving from supraliminal incompetence to subconscious competence is accompanied by confusion; moving from subconscious competence to supraliminal competence is accompanied by joy and satisfaction (Beyer, 2013).

In maintaining cognitive and emotional support at each stage of competence development adult educator plays the key instructional/facilitator roles outlined by R. Hiemstra: content resource; resource locator; interest stimulator; positive attitude generator; creativity and critical thinking stimulator; evaluation stimulator (Hiemstra, 2013).

Figure 1 illustrates the application of self-determination framework to adult learning context. Contextual and personal factors (autonomy supportive vs. controlling health care climate, personality differences in autonomy and intrinsic vs. extrinsic life aspirations) facilitate satisfaction of the basic psychological needs (autonomy, relatedness and competence) which foster sustained motivation and engagement of adult learners. The learning environment where effective co-constructing support in adult classroom is provided through a variety of active and interactive methods is described further.

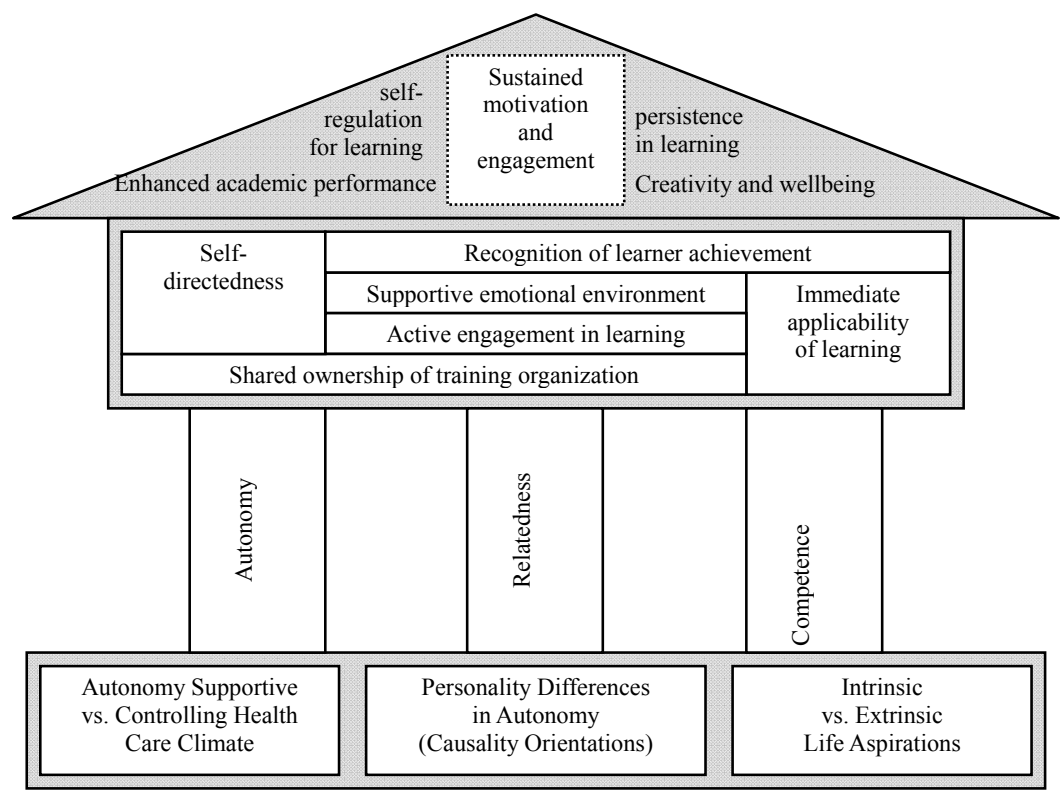

Figure 1. Application of self-determination framework to adult learning context 


\section{Materials and Methods}

Theoretical foundations analyzed in the overview served the basis for development of more efficient in-service training programs at Lobachevsky State University of Nizhni Novgorod, Russia, to foster competence development as well as sustained motivation of adult participants.

The following methodology was operationalized through the development of a syllabus for the faculty in-service training programs aimed at developing cognitive, communicative and reflective competences of adult learners (Shvetz, Levina, Mariko, \& Grudzinskaya, 2011).

Active and interactive methods of teaching and learning presupposed that the subjects of the activity participated in it with awareness of their personal goals. Application of these methods in different subject areas can be viewed in numerous educational kits developed in UNN for adult learners (Shvetz \& Krasnodubskaya, 2011).

As active and interactive methods themselves do not ensure development to achieve this goal they were used in system (when methods are chosen in order to reach certain objectives) and in the framework of an activity-based instructional theory of practice that involves the learner in setting goals. A competence-based approach was implemented through systematic use of ERR (evocation - realization of meaning - reflection) framework (Meredith \& Steele, 2011) as an inclusive model and a mechanism for organizing active teaching which promotes development of basic competences (cognitive, communicative and reflective) that, in fact, represent the components of critical thinking, through engaging the learners intellectually and emotionally in an interactive process of learning (Mariko \& Shvets, 2011).

Each stage of ERR model corresponds to a stage of the learning process organized with the help of pedagogical and methodological means. Certain processes prevail at each stage of ERR scheme and these processes give a chance to "build up" learning in full correlation with the organizational structure of the learning process. At the evocation (anticipation) stage - realization of need, provision of motive, establishing of self-directed purposes (which includes choosing a way to realize the motive, planning activity and ways of action). At the stage of Realization of meaning (building knowledge) - organized active cognitive engagement and support to the learner's monitoring of understanding new information by using methods adequate to this very content (achieving specific objectives through performing actions and procedures that activate acquisition of content). At the Reflection (consolidation) stage - getting the outcome that realizes the motive and to this or that extent satisfies the need.

ERR scheme finds application in various educational contexts: in-service training (Mariko \& Mikchailova, 2011); educational materials for independent work (Levina, 2011); reference points for development and implementation of competence-oriented educational curricula (Kostin, Chionova, ... \& Markar'yan, 2013).

Scaffolding was used as an approach allowing through a variety of methods to organize constructive participation in the adult classroom mediating joint and individual action when the more expert partner adjusted the level of scaffolding to the conceptual level and needs of the learner. Scaffolding was understood as a co-constructive process in which a more knowledgeable person (an educator or a group mate) provides hints, reminders, and cognitive supports at a level just above a learner's current cognitive level for a task. Hence, when learners build new knowledge together, they are often able to interactively support each other's understanding, effectively providing a "scaffold" to bridge what the learners could each do alone to a more complex level learners can achieve with a bit of co-constructive support (Van de Pol, Volman, \& Beishuizen, 2010).

Scaffolding strategies were chosen with consideration of the individual and collective zone of proximal development according to Vygotsky's theory and it followers (Saxena, 2010; Nesbit, \& Adesope, 2013) to properly administer scaffolding that will provide adult learners with both challenging (offering an optimal cognitive gap) and supporting (allowing the learner to complete as much of the task as possible, unassisted) learning experiences, ensuring transition from subconscious incompetence to supraliminal competence.

Individual and group-directed scaffolding was focused on selecting educational materials and their sequencing; linking students' prior knowledge and experience with the purposes of the lesson; structuring students' participation and interaction; providing appropriate verbal and non-verbal cues, and was implemented with the help of specially selected active and interactive methods.

\section{Results}

Modernization of higher education in Russia determined by current socioeconomic situation states the need in pedagogically sophisticated faculty. Rapid pace of global and regional processes makes it almost impossible to predict what conditions present freshmen will be faced with after graduation. Society has great expectations for higher professional education as the leading resource of the development of the country which is partly reflected 
in the concept of educational reform. However, some of the crucial issues, for instance, the new vision of an educator implementing the reforms are not outlined in any legal documents regulating the new educational environment.

State regulatory documents put special emphasis on innovative (competence-oriented) character of higher education. Current Federal State Standards for higher professional education established by the Ministry of Education and Science of Russian Federation specify new requirements for: learning outcomes/ the results of mastering educational curricula (acquired knowledge, skills and competences); for the structure of educational curricula (modularity); conditions of realization of the curricula (introducing competence-oriented forms and methods of teaching and learning, increase in the amount of student's independent work) (Thurman \& Efimova, 2014).

The above-mentioned requirements define basic elements of the new Standards. Some of these elements (competence-based approach to teaching and learning; modular-rating structure of syllabi; ECTS grading scale; increase in the amount and role of student's independent work; intensive use of active and interactive teaching and learning; competence-oriented assessment) are new for Russian higher education.

Challenges that educational reforms present are rooted in still domineering tested by centuries of implementation traditional approach to methods of teaching in the institutions of higher education in Russia (Avralev, N., 2013). The majority of faculty in their regular teaching practice focus on teaching content; do not involve students in setting goals; operate with a limited number of active and interactive methods, mostly understanding modernization as brining technology to class (which is also not systematic so far); underestimate the value of professional development outside their discipline.

\section{Discussion}

Assumption of the key role of pedagogues and their proficiency level in the current educational reform in Russia explains our concern in the development of an efficient system of in-service training. The system of in-service training at UNN is aimed at sustainable professional development of the faculty able to ensure a high quality of education It implies adequate and time-wise response of the system (its structure, form and content) to the demands of the society (Avralev \& Efimova, 2013).

Motivational and other theoretical issues of adult learning specified in the article were applied to professional pedagogical development of mature self-confident faculty members through innovative in-service training. We tried to address the most burning issues specific for this target audience that demonstrates subconscious incompetence level of readiness for response to new educational standards requirements.

The following charts illustrates how the suggested innovative autonomy-supportive training strategies and methods in ERR framework correlate with focal points of the motivational theory in application to the objectives of the lesson.

Table 1. Lesson information

\begin{tabular}{ll}
\hline Module & "Tolerance and Critical Thinking" \\
Topic & "Changing face of a Nation" \\
Target group & UNN junior faculty \\
Language of instruction & English \\
Objectives & 1) developing communicative skills; \\
& 2) developing cognitive skills; \\
& 3) clarifying the concept of tolerance; \\
& 4) developing research skills; \\
& 5) developing pedagogical skills. \\
\hline
\end{tabular}

Table 2. Training strategies and methods in ERR framework correlate with focal points of the motivational theory in application to the objectives of the lesson

\begin{tabular}{|c|c|c|c|}
\hline Stage & Activities & $\begin{array}{l}\text { Adult learner's } \\
\text { needs to be met }\end{array}$ & Educational tools \\
\hline & \multirow[t]{3}{*}{ Throughout the lesson } & $\begin{array}{l}\text { Awareness of } \\
\text { "incompetence" }\end{array}$ & $\begin{array}{l}\text { The English language for speaking, reading, } \\
\text { writing and listening: } \\
\text { Authentic English text; discussion of terms } \\
\text { "tolerance" and "critical thinking"; } \\
\text { ERR-scheme, pedagogical reflection }\end{array}$ \\
\hline & & Competence & $\begin{array}{l}\text { Immediate applicability of learning at every } \\
\text { stage of the lesson }\end{array}$ \\
\hline & & Relatedness & $\begin{array}{l}\text { Recognition of learner 's achievement at } \\
\text { every stage of the lesson }\end{array}$ \\
\hline
\end{tabular}




\begin{tabular}{l} 
Stage Activities \\
\hline Divide the class into 5 groups (5 people in each group). \\
How do you understand the word "tolerance"? \\
Which point on the list is most significant for you? Why? \\
Look at the photos which are used in the article we are going \\
to discuss today. \\
Make predictions what the text may be about. \\
The title of the article is "The changing face of America". Do \\
you see the connection of the key words and the title? How \\
does the title enrich your assumptions about the text? \\
Read the text individually using the list of difficult words, if \\
necessary.
\end{tabular}

Discuss the text with your groupmates to clarify the meaning

Working together:

Sum up the plot of the text and present the summary using the flipchart

Present possible discussion points using the flipchart

Find in the text information about the people in the photos. Prepare to share it with the rest of the groups answering the question: What ideas of the author these examples illustrate? Use the flipchart for your presentation.

Explain how you understand the paragraph: "The Census Bureau is aware... the answer will be used". Illustrate your opinion by examples from the text or your own examples. Use the flipchart for your presentation.

Discuss how you understand the word "DIEversity" given in the text. Pay special attention to the context. Use the flipchart for your presentation.

Group presentations. Take notes on the ideas that attracted your attention.

Individually write 2-3 sentences about how you will identify yourself.

Explain the basic principle of your identification (ethnic, religious, cultural, etc.).

Share what you've written in your group.

A representative of each group collects the papers. These five representatives organize the information using any graphic organizer and present "the face" of the class.

F Meanwhile the rest of the students working in their small groups go back to the text and discuss if they can see correlation of the processes described in the article to the ones going in Russia.

Groups of four present their ideas.

"The face" of the class is presented.

At the end of the class the following questions are discussed: Has your concept of "tolerance" changed and how? What helped you to work with the issue? What made the work difficult? What did you personally find the most important today?

Debriefing. Discussion points:

ERR scheme: lesson stages; objectives of each stage; used methods and strategies.

Analyzing the competences that are developed Analyzing motivational factors

Adult learner's
needs to be met

Relatedness

Autonomy

Competence

Relatedness

Scaffolding

Autonomy

Competence

Scaffolding

Scaffolding

Scaffolding

Autonomy

Competence

Scaffolding

Competence

Relatedness

Scaffolding

Autonomy

Competence

Relatedness

Scaffolding

Relatedness

Scaffolding

Autonomy

Competence

Relatedness

Competence

Relatedness

Scaffolding

Autonomy

Competence

Scaffolding

Scaffolding

Competence

Scaffolding

Competence
Heterogenic groups according to subject area,

competency in English and pedagogical experience

Think individually for 2 minutes

Share in heterogenic group

Pause, Ask Questions, Pause, Review

The trainer makes a list of ideas on the board

Pause, Ask Questions, Pause, Review

The trainer underlines the points that are mentioned

Use visual aids (photos).

The trainer puts down the predictions on the board using key words

Pause, Ask Questions, Pause, Review

Key words are added on the board

Pause, Ask Questions, Pause, Review

The list of difficult words

Instructions to the group work on the article.

Give enough time to read the text

Participants with a higher level of the English

level help the others to understand the text

before fulfilling the group task

Give enough time to discuss the text

Each member of the group begins to perform

a role relevant to his/her abilities (to write the words, generate ideas, prepare the presentation)

Abilities of every group member are realized, compensated and summed up with the abilities of the rest of the group participants

Peer evaluation

Mutual support

Use visual aids (graphic organizers, pictures, and charts)

Give enough time to talk and makes group's product.

Supportive emotional environment

Self evaluation and peer evaluation of group learning outcomes

Use visual aids (graphic organizers, pictures, and charts)

Addressing individual experience and personality

Application of new knowledge

Supportive emotional environment

Application of new knowledge

Supportive emotional environment

Use visual aids (graphic organizers, pictures, and charts)

Reflection of content, interaction and interrelation

Pause, Ask Questions, Pause, Review

Restoring lesson plan on the flip chart

Reflection of the educator's pedagogical activities

Handout with descriptives of communicative

and cognitive competences

Supportive emotional environment 


\section{Conclusion}

Using the theories of motivation and relevant methodology as a grounded basis for autonomy-supportive educational practices of university faculty, adult educators promote sustainable professional development of the faculty novice in pedagogy. They provide cognitive and emotional support in the individual and collective zone of proximal development of in-service training participants and raise their awareness of personal pedagogical competence and potential (Mariko \& Mikchailova, 2013). Active and interactive methods that the participants acquire throughout the training turn into their personal instrumental kit for designing competence-oriented ERRbased lesson plans, syllabi and curricula and bringing scaffolding to the university classroom (Gorylev \& Grudzinskzya, 2011).

Growth in motivation for pedagogical insights into learning outcomes stimulates the faculty's efforts to design innovative educational materials in specific subject areas (Petkov \& Grudzinskzya, 2011).

\section{Acknowledgments}

We would like to thank our colleagues Dr. Elena Grudzinskaya and Prof. Irina Shvetz for years of partnership in leading in-service training at Lobachevsky State University of Nizhni Novgorod and the joy this team work gives. We also wish to thank RWCT IC Board for the opportunities for professional development and RWCT IC members for cooperation.

\section{References}

Avralev, N. (2013). The Process of Merging Universities as One of the Key Tools to Improve Their Competitiveness and Strengthen the Rating Positions in the Global Market of Educational Services. World Applied Sciences Journal, 25(9), 1378-1382.

Avralev, N., \& Efimova, I. (2013). The Role of the International University Network Organizations in the Innovative Development of Russia. Middle-East Journal of Scientific Research, 14(10), 1277-1291.

Beyer, M. (2013). Zukunftslust statt Karrierefrust. Retrieved March 11, 2013, from http://www.mb-seminare.de/ frustlust.html

Deci, E. L., \& Ryan, R. M. (2012a). Self-determination theory. In P. A. M.,Van Lange, A. W. Kruglanski, \& E. T. Higgins (Eds.), Handbook of theories of social psychology (Vol. 1, pp. 416-437). Thousand Oaks, CA: Sage.

Deci, E. L., \& Ryan, R. M. (2012b). Motivation, personality, and development within embedded social contexts: An overview of self-determination theory. In R. M. Ryan (Ed.), Oxford handbook of human motivation (pp. 85-107). Oxford, UK: Oxford University Press.

Deci, E. L., Ryan, R. M., \& Guay, F. (2013b). Self-determination theory and actualization of human potential. In D. McInerney, H. Marsh, R. Craven, \& F. Guay (Eds.), Theory driving research: New wave perspectives on self processes and human development (pp. 109-133). NC: Information Age Press.

Gorylev, A. I., \& Grudzinskzya, E. Yu. (2011). The Order of Passing a Law in Russian Federation (p. 43). Nizhni Novgorod: NNGU. Retrieved October 10, 2014, from http://www.unn.ru/books/resources.html

Hiemstra, R. (2013). Self-Directed Learning: Why Do Most Instructors Still Do It Wrong? International Journal of Self-Directed Learning, 10(1), 25-26.

Jézégou, A. (2012). Towards a Distance Learning Environment that Supports Learner Self-Direction. International Journal of Self-Directed Learning, 9(1), 11-23.

Kostin, I., Chionova, N., Teleshova, I., Echenique, V., Ulyanova, M., Vosttrikova, E., ... \& Markar'yan, Y. (2013). Reference Points for the Design and Delivery of Degree Programmes in Management (p. 64). Bilbao: University Deusto.

Levina, L. M. (2011). Organizing Students' Independent Work in Transition to Two-level System of Higher Professional Education (p. 95). Nizhni Novgorod: NNGU. Retrieved March 10, 2014, from http://www.unn.ru/books/resources.html

Mariko, V. V., \& Mikchailova, E. E. (2011). Using Discussion Forms of Teaching for Development of Student's Communicative Competences (p. 242). Nizhni Novgorod: NNGU. Retrieved October 10, 2014, from http://www.unn.ru/books/resources.html

Mariko, V. V., \& Mikchailova, E. E. (2013). Reflexion in pedagogical activity: Stages of a becoming and tools the development. Vestnik NNGU im. N.I. Lobachevskogo, 6(1), 35-40. Nizhni Novgorod: NNGU. 
Mariko, V. V., \& Shvets, I. M. (2011). Development of the Teachers' Professional Competences: a System of Course Opening-up Based on the Competence Approach (p. 207). Caarbrucken, Germany: LAP LAMBERT Academic Publishing GmbH \& Co.KG.

Meredith, K., \& Steele, J. (2011). Classrooms of Wonder and Wisdom: Reading, Writing and Critical Thinking for the 21st Century (p. 172). Corwin.

Nesbit, J. C., \& Adesope, O. O. (2013). Concept maps for learning: Theory, research and design. In G. Schraw, \& C. T. Greenwich (Eds.), Learning Through Visual Displays (pp. 303-328). Information Age Publishing. View in a new window.

Petkov, V. I., \& Grudzinskzya, E. Yu. (2011). Isomorphism. Solid Solutions (p. 144). Nizhni Novgorod: NNGU. Retrieved October 10, 2014, from http://www.unn.ru/books/resources.html

Rodikov, A. S. (2010). Concept about the Chief's Subconscious Incompetence and Supraliminal Incompetence in European Educational Models. Retrieved October 10, 2014, from cyberleninka.ru/article/n/ponyatie-obosoznannoy-i-neosoznannoy-kompetentnosti-rukovoditelya-v-evropeyskih-obrazovatelnyh-modelyah

Ryan, R. M., \& Deci, E. L. (2013a). Toward a social psychology of assimilation: Self-determination theory in cognitive development and education. In B. W. Sokol, F. M. E. Grouzet, \& U. Muller (Eds.), Self-regulation and autonomy: Social and developmental dimensions of human conduct (pp. 191-207). New York: Cambridge University Press. http://dx.doi.org/10.1017/CBO9781139152198.014

Saxena, M. (2010). Reconceptualising teachers' directive and supportive scaffolding in bilingual classrooms within the neo-Vygotskyan approach. Journal of Applied Linguistics and Professional Practice, 7(2), 163-184.

Shvetz, I. M., Levina, L. M., Mariko, V. V., \& Grudzinskaya, E. Yu. (2011). Modern Teaching Methods in the Context of New Federal State Educational Standards (p. 126). Nizhni Novgorod: NNGU. Retrieved March 10, 2014, from http://www.unn.ru/books/resources.html

Shvetz, I., \& Krasnodubskaya, S. (2011). Active Methods of Teaching the Course "Concepts of Contemporary Natural Science" (p. 129). Nizhni Novgorod: NNGU. Retrieved October 10, 2014, from http://www.unn.ru/books/resources.html

Thurman, P. W., \& Efimova, I. (2014). Use of rankings to improve global competitiveness of Russian's higher education institutions and technology exports. Life Sci J, 11(11), 285-289

Van de Pol, J., Volman, M., \& Beishuizen, J. (2010). Scaffolding in Teacher-Student Interaction: A Decade of Research. Educational Psychology Review, 22(3), 271-296. http://dx.doi.org/10.1007/s10648-010-9127-6

Vansteenkiste, M., Niemiec, C. P., \& Soenens, B. (2010). The development of the five mini-theories of self-determination theory: An historical overview, emerging trends, and future directions. In T. C. Urdan, \& S. A. Karabenick (Eds.), Advances in motivation and achievement (Vol. 16A - The decade ahead: Theoretical perspectives on motivation and achievement, pp. 105-165). London: Emerald Group Publishing Limited.

Wilkesmann, U., \& Schmid, C. J. (2014). Intrinsic and internalized modes of teaching motivation. Evidence-based HRM, 2(1), 6-27. http://dx.doi.org/10.1108/EBHRM-07-2013-0022

\section{Copyrights}

Copyright for this article is retained by the author(s), with first publication rights granted to the journal.

This is an open-access article distributed under the terms and conditions of the Creative Commons Attribution license (http://creativecommons.org/licenses/by/3.0/). 